\title{
Morocco and Transition to Democracy: The Enduring Struggle
}

\author{
Ghazali Bello Abubakar \\ Department of Political Science, Sokoto State University, Sokoto, Nigeria
}

Email address:

alghazel@gmail.com

\section{To cite this article:}

Ghazali Bello Abubakar. Morocco and Transition to Democracy: The Enduring Struggle. History Research. Vol. 7, No. 2, 2019, pp. 56-64. doi: 10.11648/j.history.20190702.15

Received: April 27, 2019; Accepted: June 4, 2019; Published: November 25, 2019

\begin{abstract}
The occurrence of the dual unforgettable incidents namely 'Cold War' between the two superpowers, the United States and the former United Soviet Socialist Republic (USSR) and fall of the Berlin Wall, Moroccan authorities consolidated what could be seen as "fundamental background" of the democratization process. With the help of modernity, Moroccan monarchy has been able to incrementally install a systematic equilibrium that could match the contemporarily modern democratic style. The authorities, however, focus on political and civic organizations. The flexible nature of this nation coupled with absolute amenable behaviour to embrace democracy as a new style very much help in keeping the kingship system on the stance at least for now and time to come. This has become clear during the popular political revolts of 2011 when Moroccans in large numbers demanded modifications and changes instead of toppling down the ancient system at whole. Islam reached Morocco somewhere during the first century of the Hijra (migration), and since that time, the kingship remains the style of leadership in the country until today.
\end{abstract}

Keywords: Democratization Process, Moroccan Regime, Reforms, Hassan II Era, Roles of King Muhammad VI

\section{Introduction}

For the past several decades, Kingdom of Morocco has become one of the central realms of the world powers. Long ago, donor and pro-democracy nations have been emphasizing peace and political transition, human rights, and transparency in the country. Additionally, the historical linkages and relationships that the Kingdom of Morocco maintains with the Western world including the United States are tremendously serving an outstanding remark in transforming and preparing Morocco for the current political scenario (except for the Western Sahara). It is very difficult for Morocco to suddenly switch-off her ancient style, which was in the place for more than 1300 years back, to adopt a newly democratized style.

Perhaps, abolishing kingship style and put in place democratic leadership could not be unsurpassed for Moroccan current political and economic situations. Therefore, the sluggish step-by-step mechanism seems quite proper in order to embrace full and stable democratic system in this country whose citizens are dominantly Muslims. Democracy could be good for people of countries such as
Egypt, Libya, Tunisia or any "Third World" states if applied on an incremental approach depending on the background of leadership on the ground and orientation of citizens of any given nation.

The Kingdom of Morocco is said to be one of the moderate Arab-Muslim states, likewise the Hashemite Kingdom of Jordan. However, in terms of transition to representative and liberal democracy, Morocco proves to be heavyweight since 1990s. So many factors contribute in achieving regular peaceful transitions including geographic proximity to the countries of south Europe, which has brought about many influences on Moroccan culture, tradition and language. Secondly, the country's old friendship and relation with the United States, the biggest producer of modern and liberal democracy, is another added value.

It is beyond doubt that these factors must have helped Morocco shaping her future political ambition. Compared to the previous past, many improvements are recently witnessed in various walking of life; freedom of speech is wider, enlarging political participation, more chances for civil society groups, etc.

To sketch out roles played by the Moroccan regime in 
order to ensure consolidation of democratization process, this study looks at some key areas including nature of conducting elections, social issues like education, health, transportation, and other social amenities. Lack of these facilities could effectively undermine the ongoing process.

\section{Conceptual Clarification}

The word 'Democracy' that signifies absolute free will of peoples to elect who should govern their affairs is nonEnglish origin neither a modern concept. Rather, it gets its fertile ground in the primordial time. Like many 'cracy' ending words, such as aristocracy, bureaucracy and so forth, 'democracy' is a product of Ancient Greece. For Greek lingua-franca of Indo-European language family (Hellenic language), 'Demos' stands for 'peoples' or 'many', while 'kratos' and/or 'cracy', in modern English letters, means, 'power' or 'rule'. Therefore, the modern definition of democracy is nothing but the rule of the people, by the people and for the people, where everyone has an equal share, alike as promoted by Abraham Lincoln.

The word 'democracy' according to David Held came into English vernacular somewhere in the sixteenth century from the French democratie, while its origins were Greek. 'Democracy' connotes a form of statecraft in contradistinction to monarchies and aristocracies of the people rule. Democracy entails a political community in which there is some form of political equality among the people. The history of the idea of democracy is complex and marked by conflicting conceptions. There are plenty scopes for disagreement [1].

Democracy is seen as a system in which, both rulers and ruled, govern, share and involve in general policy decisionmaking with equal power. Democracy has been also recognized and chiefly treated as the best form of government. In other words, the concept is just opposite of autocracy, monarchy, dictatorship, authoritarianism, absolutism, oligarchy, hierarchy tyranny or any kind of arbitrary ruling. Out of the above different forms of governments, no single form prolongs to serve the cause of the people directly. Therefore, the exponents of "democracy" got and are still getting popularity in advocating the suitability of the democratic form for the global setting of today simply because it seems to go side by side with good governance and humanitarian considerations. Prominent scholars, such as John Austin (1790-1859), A. V Dicey (1835-1922) and A. L Lowell (1856-1943) were some of the exponents of the democratic system of government.

\subsection{Theoretical Framework}

Putatively, democracy appears to be the most accredited system that has developed an apparatus to balance between the two classes, rulers and ruled and claims to be a government of all as mentioned above. Since it is emerging as universal norm; good governance is always expected in its platform. R. M. Dworkin highlights that, democracy means government by the people. Nevertheless, what does that means? Among political theories or in the dictionary, no explicit definition of democracy is settled. On the contrary, it is a matter of deep controversy of what democracy really means [2].

As a form of government, somescholars defined democracy as a source of authority for government, purposes served by government, and for constituting government [3]. No doubt, it is believed that democracy should be the best system to administer people compared to the non-democratic regimes, which many, however, adduce to be incapable ideal form of leadership. Democracy requires strong local government, multiparty system, equal participation and political rights of citizens, civil liberties and the multitude of nongovernmental organizations. A stable democracy needs a certain level of both social and economic well-being, including widespread literacy, urbanization and high per capita incomes.

In the formal foundation of democracy, history shows that, apart from Ancient Greece, the society considered the pioneer of the ideological concept; different societies and cultures were being governed through the intermediate by democratic means; from Indian society, Mesopotamian, Phoenician, Ancient Rome, Europe and Americas. The Westphalia's treaty of 1684 brought about the formation of sizeable nation-states, particularly after the following congress of Vienna, the first part of the series of meetings held on the name of "concert of Europe" in 1815. Again, that created a new political boundaries for the numbers of cities and territories in Europe itself, i.e. Saxony city of Germany, France, some of the Italian cities, Netherlands, Duchy of Warsaw, etc. the congress was to identify the imbalance of power in Europe and to discuss the alternative solutions available. However, it is stood as a model of latterly international organizations, League of and United Nations. In a broader sense, more or less, the series of the held meetings served to democratize geopolitical demarcation in Europe.

The process of democratization is rooted in the political struggle. Scholars like Dankwart Rustow believe that the process should contain well-entrenched forces of typical social classes. This struggle is likely to start because of the appearance of the new elite, which would unite diverse public groups into a combine battle [4].

Meanwhile, the "third wave of democratization" as synthesized by Huntington has gradually changed the map of the world since the late 1980s. The transitions in many Asian countries such as Philippines, Taiwan and South Korea preceded the dramatic collapse of communism in Eastern Europe and a new democratic system emerged in their places. These waves however, move to Africa and Middle East as well. Thus, this is strengthening democratic camp in international organizations and weakening the communistic block as alternative ruling ideology. Nevertheless, this evolution enables democracy and human rights to gain new status in the global level of reference for modern statehood and legitimate ruling. A number of democratic states rose after the collapse of Soviet Union and other communist regimes and end of Cold War respectively. Yet the current 
observation poses a question whether these states are truly democratic or the exercise of the real power still rests with autocrats.

Many studies on the process of democratization pay much attention on the concept of civil societies and their competencies to encourage the process and demonstrate its positive roles in transition from authoritarianism to sustainable administration. Hence, building an athletic civil society is perhaps precondition for democratization and its consolidation especially in the third world nations. The very common examples are recent revolts in the Arab world, from Tunisia, Egypt, Libya, Syria, Yemen, to the state of Bahrain and so forth. According to Huntington, individual agents are very important in the transition to democracy. Democracies created not by causes but by causers. To him, the transition was based on elite choice, participation, beliefs, and actions while subsequent consolidation was based on elite pacts and consensus.

\subsection{Monarchism and Democratization: $A$ Worldwide Phenomena}

By early of the $21^{\text {st }}$ century, monarchy was no longer championed by many, after isbeing considered as a system that failed to sustain its prolonged existence for a longer period due to the autocratic type of its nature. But still the monarchy in many countries in Europe, Africa and Asia, led and becomes a doorway for democratization. In Western Europe, multiple monarchies do exist. Region-wide, these monarchies have very much contributed to democratization processes. That is what has subsequently been known as 'Constitutional Monarchies'. In fact two of the foundingmembers of the European Coal and Steel Community, the body that would become EU later on, namely Belgium and Luxembourg are now among the constitutional monarchies. However, many of these monarchies are now enjoying full membership of the regional organization (European Union [EU]). Democracy and promoting rights of peoples top the prime concerns of these countries wish to join EU in the region.

More or so, throughout its enlargement process, from 1951 onward, the Union awarded full memberships to many European constitutional monarchies including Belgium, Denmark, Luxembourg, Netherlands, Spain, Sweden, and the United Kingdom (in pre-Brexit). Regardless of the types of these monarchies: constitutional, popular etc. but it's beyond doubt that somewhere between $16^{\text {th }}$ and $19^{\text {th }}$ centuries, if there was a system that seemed alternative to monarchy, it had been a system with no popularity compared to $20^{\text {th }}$ and $21^{\text {st }}$ centuries. Similarly, in Asia, countries like Bhutan from the south; Brunei, Cambodia and Malaysia from the southeast and Japan from the east, and of course, Morocco the only monarchy in North Africa, inject toward democratization and act as catalysts for change of system in their countries.

In Europe history shows that some conflicts of interests between church and state occurred. For instance in England, Henry VIII withdrawn from Catholic Church and established the Church of England after Catholic prohibited him to divorce his wife whose could not produce male heir for him. In Italy the new monarchy emerged after the incidence of 'Black Death'. Monarchy supports the middle class people and traders not only because of their needs to government intervention but also because they stand as strong and reliable source of taxes and revenues generation.

These heavy taxes, economic and political domination of the monarchs at that time coupled with awareness of the communities were among other reasons that alerted those monarchs and helped them to decentralize their powers to the elected body. That was long process carried out over the period of hundreds of years.

Categorically, in Bhutan for instance, in 1999 King Jigme Singye Wangchuck brought and pioneered wonderful reforms in the Kingdom of Bhutan, the first of its kind across history of the country. Through the new revised constitution presented publicly in 2005, King Wang chucks surrendered most of his powers to the cabinet ministers. Impeachment of the king by two-third of the majority in the national assembly was initiated; freedom of expression expanded, whereupon bans on televising and internet communications were lifted.

Tremendously, it was indeed successful contribution that left an utmost paradigm in the region. Importantly, some countries with mixture of monarchies as symbolic and parliamentarian democratic elected government such as Japan, have more than one time responded positively in a situation where a democratic civil rule overthrown by military dictatorship or some other type of coup d'état. Despite being a country with monarchic regime (constitutional), Japan practically remains anathema to nondemocratic system of government. For instance, in 1991 because of the coup in Haiti, Japan froze its Official Development Assistance (ODA) until 1994 when JeanBertrand Aristide was restored, whereupon ODA resumed in 1995 to the new democratic regime.

\subsection{Democratization Process: The Middle East Vision}

Foreign Aids of course motivate Moroccan consolidation, but the regime has already kicked off to move for more opening. Moroccan regime, after many centuries has finally proved a litmus-test of its commitment to carry out transformation processas early as 1956 and 1960. The immediate first years of post-independent Morocco, though many experts observed what could be 'meretricious move' simply because what regime showed to outside world in documents was obviously different from reality. But it has also been learnt that, the Moroccan regime, regardless with many shortcomings that appear during this process, still some certain level of adaptabilities such as conscious will and readiness to process are seen through.

Until recently, Moroccan monarchy proves its seriousness on democratization over numbers of multiple activities such as inviting different political organizations to participate in political life of the country, freeing political prisoners, different constitutional reforms, changes in the Makhzen i.e. replacing the interior minister, expanding the freedom of 
press and civil society organizations, and the biggest one is holding regular elections including the credible one of 2011, which allowed the Islamist party (PJD) to form a coalition government led first by Abdelilah Benkirane as per 2011. Constitutional monarchy also needs time to stabilize, but still some positive outcomes are witnessed. Thus it was good beginning for Morocco.

Lise Storm stressed that during the seven years, between 1990 and 1996, Moroccan regime managed to improve in human rights condition and revised two constitutions: 1992 and 1996 that has latterly become a watershed in terms of political history of the country [5].

Moroccan monarchy seems to deliver this process through some three main areas namely: political opening, constitutional modifications and human rights. There are also other forms in which monarchy tries to convey the same endeavouring message. Some of them of course, are successful and others encounter failure. Frankly, each one of these categories is escorted by one or more reasons. Be it dual attempted coup d'état during the 1970s, widespread riots in the country or even international pressure groups.

\section{Roles of the Moroccan Regime in Democratic Transition}

In the last decade of his reign between 1990 and 1999, King Hassan II had tried to transform and simplify the living of ordinary Moroccan citizens. The King however, introduced political opening in Morocco after it has been stasis for many years. Besides, many initial programs remained unattended. The new international climate that came at the end of the Cold War strongly supported a wide range of democracy. That was considered as external pressure on Moroccan monarchy so that it can conform to the new trend mounted during the 1992 categorically after European Parliament denied aid package because of poor performances in human rights as mentioned above.

At domestic level, the drought becomes a major factor in terms of increasing urbanization. This resulted in unprecedented levels of unemployment and discontent. Therefore, this slowly changes maximize support to the Islamist groups as the only opportunity that Moroccans were able to seize. But as far as the regime is concerned, this means all but threatened danger to the throne.

At early time of the 1990s, Moroccan monarchy found itself in a very fragile position. Several different factors account for this phenomenon; probably the most important was the Gulf War, which has affected Moroccan politics. Three developments were of particular importance: first was the traditional opposition - dominated by the Istiqlal and the USFP - grew in strength as these parties came together and opposed the Gulf War, challenging the monarchy simultaneously. Second was the Gulf War which resulted in political unrest, as the citizenry took to the streets of every major city on 14 December 1990 and demonstrated against the war as well as against the Moroccan authority for sending troops to the American basement in Saudi Arabia to pledge war against Saddam. It was driven by sole interest of the United States, which to them, was no less than dominating force over Middle Eastern affairs. Third was partially a result of a general trend of Islamist resurgence in the Middle East, and partly as a result of dissatisfaction with the already existing channels of popular participations, an increasing number of Moroccans chose to join the Islamist movements, particularly Abd al-Salam Yasin's Al-adlwal-Ihsan or Justice and Charity [5].

In pre-Gulf War, Morocco has significantly achieved progressive changes in its democratization agenda including constitutional revisions. Thus, the monarchy however, had altered the title of the Kingdom from absolute to constitutional monarchy, in accordance with the type of the government operating thereupon. Despite these popular improvements, the progress seems very much ephemeral as the permanent institutional pillars, which allow unrestricted power continues to rest with the King were missing. No doubt, the municipal as well as legislative polls were held on a regular basis, and with transparency.

During the 2003-04 King Muhammad VI has decisively moved to reform the family code. Notwithstanding the personal rights together with other major international conventions were substantially improved, the rate of human rights violations remained high since the Casablanca's catastrophic bombings in May 2003. Corruption is another chief issue that the grand process encountering. The Moroccan palace has been working for the priority of the rule of law immediately after the incumbency of Muhammad VI in 1999. The efforts are seemingly fruitless in yet another bombing in Marrakesh 28th April 2011, which left 17 foreign nationals dead whose were mostly Europeans.

\subsection{Improvement in the Rights of the People}

Throughout many decades, human rights, violation and discrimination against minority were very much common in Morocco. These prejudicing activities were steadily slowing down by the efforts of the King Muhammad VI who launched Equity and Reconciliation Commission (IER) to deal with the previous grievances of tortured families who suffered in the 1980s. Addition to that, the King however, enacted official dialogue in 2001 on the issue of marginalized group, notably Berber culture. Since then, teaching of the Berber dialects and culture in the public schools has now become formal matter; to advance the status of the Berber in the country's spheres more than before, the dialect has been used in writing textbooks and television programs [6].

The IER was inaugurated in Morocco, and the first in its type throughout Arab world. In August 2007, more than 193 million dollars have been spent to compensate some 23, 676 victims including some individuals, who will be having special treatment, such as jobs and other chances they might have lost during their imprisonment time. Again, the issue of human rights reforms has inextricable concern likewise the matter of disappeared people who have been vanished for their implication in military's attempts to the life of the 
monarch and in attempts to overthrow the government in 1971 and 1972. Large numbers of these peoples were either pro-Western Sahara or inhabitants of the Saharawi territory in the 1970s. The following appointment of Yousefi as Prime Minister in March 1998, has seriously promised to track over the previous cases, and tried to ensure such kind of disdain on the course of opposition never happen in future Morocco.

From 1998 till 2003, Yousufi's government has made remarkable gestures toward releasing thousand of political detainees. In this regard, Michael M. Laskier (2003) showed that in the final two years of Hassan II's reign, and the Yousefi's government was already allowed to free many prisoners. Simultaneously leading exiled political opponents and or their families were granted permission to come back to Morocco, and perhaps without changing their political sentiments as a prerequisite of their returning to their homeland. The guarantee includes Marxist activist such as Abraham Serfety and family of the late Mehdi ben Barka, who was killed in Paris during the 1960s over his political antagonism towards King Hassan II [7].

\subsection{Consolidation of the Reforms}

After returning back from exile, Muhammad $\mathrm{V}^{1}$ was the Sultan of Morocco between 1927 and 1957, and ruled as King from 1957 to 1961. During his life, Muhammad V was one of the focal nationalists who have also fought and won Moroccan independence in 1956 from France. Muhammad V was deported to Corsica and latterly Madagascar in 1951 over his rebellion against French occupation and returned in November 1955. The negotiation he made with French colonisers in March 1956 led to the full independence of Morocco. Muhammad V was deposed by encouraged and organized pro-French reactionary on allegedly account of supporting Istiqlal party, and for requesting to form selfgovernment in Morocco during the 1950s. King Muhammad $\mathrm{V}$ was the first King dreamt about modern Morocco based on liberty and political participation.

Despite his commitments and struggles to achieve independence from France, which supposed toback Morocco adopting parliamentary democracy; Muhammad V wasn't able to provide constitutional institutions could ease parliamentary system through regular elections. Though political parties were formed but their freedom and liberalization were limited. He administered all of the government's spheres and dismissed the cabinet formed by the Union Nationale des Forces Populaires (UNFP), the very party won the first post-independence elections in Morocco2 and replaced it with a new enacted cabinet. Marina Ottaway and Meredith Rileyargued that Muhammad V not only dismissed the cabinet, he consolidated power by rallying rural notables and security apparatus to himself [8].

1Muhammad V, the immediate and biological father and grandfather of Hassan II and Muhammad VI respectively, born on $10^{\text {th }}$ August 1909 in the city of Fez. He died in Rabat, the Morocco's capital of administration, on $26^{\text {th }}$ February, 1961

2 UNFP has separated from mainstreamIstiqlal (Independence) party and formed a new title after Moroccan attainment of independence from France in 1956

\subsubsection{King Hassan II: Reforms Continue}

Hassan II's era started with the death of his father, Muhammad V in 1961. Hassan II was born on $9^{\text {th }}$ July 1929 , and was the first born-child to his father. Hassan II attended religious training centre in the palace itself, which longed for two years, and later on joined the imperial college in Rabat. King Hassan II graduated from the University of Bordeaux, France. Nevertheless, he also served as acting deputy prime minister during the reign of his father. While assuming the throne, throughout his reign, Hassan II has been introducing many positives and developmental achievements particularly in democratic reformation. A year after assuming throne, a royal charter was formed followed by a constitutional monarchy.

The new constitution provides that King should be central figure in the executive branch of the government. Albeit the parliament with bicameral legislation: Assembly of Representatives and Assembly of Councillors; holds legislative power. Constitutional reforms were approved in 1970 after the 1963's legislative polls, in which royalists secured fewer seats. Over political dissent, Hassan II declared both executive and legislative branches of government under state of exception. The approved constitution of the 1970s cured up the frozen parliament, and held fresh elections, but still the government did not deal with the remaining adversarial contents, corruption and other malpractices.

Parenthetically, this was somehow, difficult circumstance for the then 32-year old monarch. After struggling to frame up the constitution followed by the elections won by opposition nationalists and leftist parties, the ideas which made them popular were derived from pan-Arab nationalism led by Jamal Abdel-Nasser of Egypt and socialism in Russia. Subsequently war broke between Morocco and neighbouring Algeria in 1963, many opposition leaders whose relatives and friends or colleagues were detained seemed to support Algeria over Moroccan monarch.

The King went on to oversee a release of political prisoners, constitutional reforms, and the inauguration of the principle of altenance, whereby the most popular opposition party was granted access to the post of prime minister in 1998. As for Denoeux and Payne, King Hassan II showed a remarkable degree of adaptability over the course of his 38year reign. He presided over a shift in the very relationship between state and society. The political opening began with a consultative phase characterized by the Conseils Consultatifs, in which broader elements of society were invited to participate in dialogue over public policy and reform movement [9]

During the 1970s, King Hassan II was confronted by different issues, which traditionally might thwart the success of the already-started process of reformation. Those issues include expanding Islamism which was among the top agendas to be dealing with; legalizing opposition parties to participate in the elections, though their political freedom and power were limited simply because of the created division, which undermine any possible threats. Meanwhile, these 
groups lacked enough political power to confront the interests of the palace.

Above all, the most significant reform that Hassan II tried to achieve during his life was the "Family Code" (the Mudawwana) Mudawwana is an Arabic word literally means "written documents", and is the title of Imam Malik's first jurisprudent Book. In Morocco, the term used as set of law under the Islamic Shari'a that contains rights and responsibilities of Muslim individuals pertaining to the interaction between among themselves at family level, such as marriages, divorces, kinship, inheritance and so forth).

Mudawwana reformation soon becomes controversial task. It influenced many Ulama' (the highly intellectual class of Muslim scholars) and chanced them to discuss such reformation keeping in mind political will. This improvement seemed very much difficult in previous time. King Hassan II has addressed the issue of reforming the Mudawwana several times during the early years of his rule, but his attempts lacked substance and real intention until the colossal changes in the world, such as the disintegration of the Cold War divide and calls for political liberalization and democratization at the end of the 1980s and beginning of the 1990s. It has become clear that the autocratic regime of Hassan II would not survive without addressing and changing its quasi-democratic and quasi-pluralistic political system allowing the political arena to be more inclusive, rather than exclusive. All of these developments concomitantly led to a revived interest in the reform of the sacredly ossified Mudawwana.

Consequently, in 2004, after a long historic struggle of more than one decade Mudawwanat al Usra emerged in a modern and revolutionary form [10]. Politically, somewhere in 1998, King Hassan II has openly invited the opposition groups to work shoulder-to-shoulder in forming historical transition to democracy for the first time in the past 38 years. Hassan granted the post of Prime Minister to Abdur-Rahman Yousefi, who was opposition leader. Many experts believe that this opening was of great value not only on political sphere but also on economy too.

In the early 1980s, Moroccan economy was sick and thus needed lot of systematic reformations. The first attempt was said to be Structural Adjustment Program (SAP) launched in 1983. The state sought to redress its slide toward bankruptcy by working out an agreement with the International Monetary Fund (IMF) that further constrained spending on debt-ridden public sector. The austerity programs however, watered down and postponed as hope for private investment failed to materialize to the degree needed to jumpstart rapid economic growth. Underemployment continued to soar, reaching an estimated 22 percent of the work force in 1999. The growing pockets of the poor in the bidonvilles that sprouted up around the large cities; were cause for concern as the state was increasingly unable to provide for their welfare

\subsubsection{Democratization Process in the Post-Hassan II's Era}

The 1999 marked the year when the throne of a Moroccan palace passed to Muhammad VI through the means of inheritance after his 70 years old father passed away. During his administration, King Hassan II played a key role in the Middle East peace process, and become a staunch ally of the United States. He had also become a very important figure in the Gulf War, by mobilizing troops as part of Morocco's coalition against Saddam Hussein's invasion of Kuwait [11]. Whereupon succeeding his father, King Muhammad VI continued to give a certain degree of consideration to the process of democratization in Morocco with attentive consideration. Just like Hashemite in Jordan and al-Sabah in Kuwait, those recognized such movements and translated them into action through the modernizing monarchical power, rather than transferring ultimate political authority into the hands of elected representatives.

King Muhammad VI from the very beginning introduced his 'action station' to the wave of reformation. Under his stewardship, Morocco has taken a number of steps to expand political pluralism, liberalize public life, and improve its human rights record. This process watched and supported by Morocco's allies in Europe and the United States, who are eager to see Morocco become a model of a democratic and moderate Muslim state, in sharp contrast to the failures of American-endorsed Middle Eastern democracy projects in Iraq and the Palestinian Authority. Apart from political liberalization and trying to include many significant changes in modern Morocco, the positive indications in the new king, Muhammad VI's reign include linkage between the Democratic Association of the Women of Morocco (ADF) and government [11].

Practically, in September 2002 elections, thirty seats reserved for women in the parliament. Regarding to the less qualitative education coupled with unemployment, many believe to be a challengeable factor to the young Muhammad VI. The new King according to Patricia, education and unemployment are key to his long term strategy for Morocco, although he was a bit bewildered about how, and where to start, while urging tax payers to pay their dues in order to fund the treasury. He has also set up a special fund to which affordable citizens can donate money that used for poverty programs. However, much of the Moroccan middle class struggles to get out of economic difficulties [11].

Two decades passed over the leadership of King Muhammad VI, as entering to the third one, the king together with other Arab leaders witness political uprisings, demonstrations and upheavals, which shook down some of their beefy regimes. To escape the possibility of masses movements as such on $9^{\text {th }}$ of March 2011, Moroccan monarchy, according to Alexis Arieff, gave nationally televised speech in which he promised a range of reforms to the political system of the country. The King has effectively appointed ad hoc commission to draft proposals for constitutional reforms. These proposals concerned much about what previous regime notably ignored like political freedom, job opportunities to the young graduates, etc. In early June 2011, the commission has submitted the proposed reforms in which it consulted with political parties, labour unions, business associations, human rights groups, and 
others.

The King moreover, expressed his certainty that the constitutional proposals include the resolution of the Western Sahara dispute [6]. Arieff added that the major political parties have spelled out their support for the draft; they also urged their supporters to vote for such proposals. The parties who announced their satisfaction with the current action taken from the palace includes the Moderates Islamist opposition Justice and Development Party (PJD). The party nevertheless, acclaimed the process as "important advance," albeit, Justice and Charity Organization (JCO) since from the grass-root of its foundation refuses to recognize King as the Commander of the faithful, (i.e. Amirul Mu'umineen).

The new strategies followed by the Moroccan palace in translating his ambitious dream of unity, equality and justice in the country were provincial visits to mostly non-Arabs tribes i.e. Berber. Lise Storm quoted Cembrero justifying that during his first year on the throne, Muhammad VI had spent a large amount of time travelling around the country in an effort to win the approval of the population by showing his commitment to Moroccans at all levels of the society and in all the country's regions.

Eventually, that earned him the nickname al-Jawal, the mobile, a word commonly used for pre-paid mobile phone cards. By early 2001, however, it had become evident that the King's strategy for winning popular support, which had worked so well during the first year of his reign, had begun to backfire as his promises of reforms failed to materialize [5].

\subsubsection{King Muhammad VI, More Democratic Morocco}

During his first days on the throne, King Muhammad VI was known as 'King of Poor'. Though some of the tactics used by him to attract common Moroccans were not direct to the point, but the young Muhammad reaffirmed his zeal to win popularity throughout Morocco. Thus, this is seen as another step to realize utmost process of liberalization. Kingdom of Morocco developed a kind of expanding chances for Moroccan society to participate and take part in the reforming behaviour of the state in various sectors.

King Hassan II was the one who for the first time, developed the idea of bicameral legislature in Moroccan parliament. This action continues to maximize massive political participation from different political orientations: secularists, Islamists and nationalists. Similarly, King Muhammad VI's ascending to the power seems 'grist to the mill'. The King launched several techniques of engaging Moroccan society for the formation of new democratic Morocco that could aptly go hand-to-hand with the modern day without exaggeration or lagging Islamic norms, which stands as total way of life for Muslims behind.

Marina Ottaway and Meredith Riley, make it clear that during the King Hassan II, dialogue and improvement in the administration of elections led to better relationships between the palace and most political parties. That is because political groups are closer to society through politicians who, during campaign normally promise to take responsibilities of satisfying basic and necessary needs of the people if elected. Accordingly, Hassan II would have been able to bring about the most visible political accomplishment of this reformist period in which 'alternance' successfully seen through. Instead of installing palace's parties to form the government as usual, King Hassan II neutralized the palace's parties and allowed USFP leader to form the then government [8].

Contemporarily, the relationship between the palace and society is increasingly becoming positive and systematic. Again, Moroccan authorities seem to be all-aware of the bulky responsibilities that they have to fulfil for betterment of the people and for better Morocco. King Muhammad VI announced and celebrated his own royal wedding in public. This happened for the first time in the history of modern Morocco. This development served a clear message that from now onward, the renewal process of social justice and equality started replacing the old restricted attitude of the palace toward its subjects.

It was very damnedest behaviour to televise Muhammad VI's marriage to then 24-year old Salma Bennani, a computer engineer graduate from Fez. This is tremendous development for Moroccans because in the past, issuing any notice regarding family or any other related matter in traditional Morocco was considered a crime against the honour of the King and Royal family. Afrol-News, the online News cable, reported that, it's highly risky to make any statements on a matter related to the members of Sharifians royal family. But during the king Muhammad VI things unusually started taking different direction. Muhammad VI broke with the Royal traditions by announcing his marriage event, while his father, the King Hassan II's marriage was announced instead of keeping it secret after Latifa (second wife), conceived.

Furthermore, the freshly unexpected move was seen through the royal family, sent a signal, not only to Moroccan people, but also to the world, that the Moroccan monarch is moving forward and becoming more responsible with moderately standard behaviours than remaining as angle sent from the heaven [12]. Fitness of the King Muhammad VI shines the palace by attracting realization of the society that the king is a ruler and protector, who comes down closer to us, listens to grievances we have, seeks our opinions in matters concerning our beloved country regardless of being the chief of all Moroccans.

The New York Times remarked on him as popular, a king who looks more like a movie star than monarch does. On a recent tour to some parts of the country, countless numbers of the peoples on streets showed their jubilant mode and welcomed him. Schools were closed, ancient markets shut down and entire families trooped to the roadside to see the young king, who arrived in their locality [13]. While in office, King Muhammad VI keeps focusing on new concepts of authority. He made popular calls to improve the condition of the majority Moroccans who live in poverty and other social malaises. However, the king conciliated Moroccans via several factors including taking another direction for wider political participation [14].

Seemingly, Morocco's aware that the social and economic 
condition are in devaluation; the King has understood that he can no longer continue to tackle these issues effectively, and retain legitimacy in the eyes of the public by turning a blind eye to the political domain [15]. However, the February 2011 demonstrations were the key points that perhaps compelled the regime to convince the people that it will engage the direct participation of the citizens in decision making, security and other domestic issues. The king however, portrayed his desire to reformation through a massive referendum that has brought about the new package of revised constitution in order to placate down potential anxiety from the people during the Arab Spring, which dominated and emerged as the main event in the entire Arab world throughout 2011. This has very much helped in paving the way for long live monarchy.

In the first weeks of the spring, the King freed close to one hundred political prisoners and invested more power in the National Council for Human Rights. He nevertheless appointed the founder of the Moroccan branch of Transparency International, Abdesselam Aboudrar, president of the national anti-corruption agency. Secondly, the level of public participation in the reform process has been positively increased compared to the previous time. Thirdly, the new constitution takes major steps forward to providing a balance of powers in which the Moroccan parliament has real authority. The prime minister has expanded powers, but the parliament will also find the threshold much lower for forming an inquiry commission and presenting a motion to censure or remove the government, compared to the absolute majority required before.

During the crises (in North Africa), although Moroccans somehow, demanded greater reform, but never called for removal of the King Muhammad VI neither they required toppling down the regime, which indicates that the relations between the state of Morocco and its subjects, especially in the reign of King Muhammad VI was smooth [16]. The country had previously experienced political reform and as a result had a general trust in the monarchy as an agent of change rather than one of repression. The relationship between society and monarchy is more or less something depending on how and where the regime places itself in the society. Many observers praised King Hassan II for his several attempts to liberalize Morocco, and put more emphasis on Middle East and North African issues particularly with relation to democratization of the Arab world in general.

Regarding to the issue of decentralizing power, King Hassan II, as the top spiritual leader of the country and commander of the faithful, not allowed surrendering all the powers that normally hold by the commander of the faithful and reign without governing [11].

In shaping political development alongside connections between the monarch and Moroccan elites, Saloua Zerhouniexplained that the monarchy is the main component of the political system and the centre around which all political actors revolve. During King Hassan II for instance, power manipulated to safeguard the king from an oppositional threat, as so as much King Hassan managed to keep changing situation and political challenges using repression, and consensus. While King Muhammad VI on the other hand, has applied the so called "reinforcement of the centrality of the monarchy," through a more liberal style, guaranteeing his predominance in politics. The act of institutionalization of the royal powers has a dual function. On one side, it is an important tool for controlling the elite by seeming to give them a voice in decision-making as well as regulating their integration into the political system, while on the other side, it is a way of affirming the pre-eminence and the efficiency of the monarchical institution [17].

\section{Conclusion}

Despite number of challenges and shortcomings encounters by Moroccan authorities, yet the Moroccan democratization agenda is considered a point of reference in the entire region. Morocco is the only country with constitutional monarchy throughout North Africa sub-region, and less affected by the recent Arab springs. Although the authoritarian type of leadership it has, supposed to attract more tension even if the uprisings are not given any consideration, but due to the regime's commitments, the country was survived with small injuries. The potential matching/mismatching attitudes of democracy and Islam however, attract attention of many scholars in the Arab and Western world. Morocco of course, becomes one of the targets point. Some scholars like Lise Storm, see Morocco as non-qualified to be considered democratic one.

\section{References}

[1] Held, David. (2006), Models of Democracy, Chicago: Stanford University Press.

[2] Dworkin, R. M (1999), Freedom's Law: The Moral Reading of the American Constitution, London: Oxford University Press.

[3] Huntington, S. P. (1991), The Third Wave: Democratization in the Late Twentieth Century. Oklahoma: University of Oklahoma Press.

[4] Rustow, Dankwart A (1973), "Transition to Democracy Toward a Dynamic Model", Journal of Comparative Politics, Vol. 2 (3): pp 337-363.

[5] Storm L (2007), Democratization in Morocco: The Political Elite and Struggles for Power in the Post-independence State, New York: Rutledge.

[6] Arieff A (2013), "Morocco: Current Issue", [Online: web] Accessed 9 December 2011 URL: http://www.fas.org/sgp/crs/row/RS21579.pdf

[7] Laskier, Machael M (2003), “A Difficult Inheritance: Moroccan Society Under King Muhammad VI", Middle East Review of International Affairs, 7 (03): 15-16.

[8] Ottaway M, Riley M (2006), Morocco: From Top-down Reform to Democratic Transition, Carnegie Paper No. 71, Carnegie Endowment for International Peace, Washington, D. C. 
[9] Guilain, Denoeux, Rhys P (2003), "Democracy and Governance Assessment of Morocco", [Online: web] Accessed 20 May 2011 URL: http://pdf.usaid.gov/pdf_docs/PNACX727.pdf

[10] Žvan K (2007), The Politics of the Reform of the New Family Law (the Moudawana), Ph.D. Thesis, London: University of Oxford.

[11] Campbell, Patricia J (2003), "Morocco in Transition: Overcoming the Democratic and Human Rights Legacy of King Hassan II", African Studies Quarterly, 7 (1): 41.

[12] Afrol News (2002), “The Morocco's Royal Wedding, Breaks without Traditions", [Online: web] Accessed 28 December 2011

URL: http://www.afrol.com/News2002/mor005_royal_wedding.htm

[13] Jehl, Douglas (1999), "In Morocco, too, a Young King for a New Generation", The New York Times, NY, 27 July, 1999.
[14] Whitney, Craig R (1999), "Popular New King Has a Goal: A Modern Morocco", The New York Times, New York, 12, November 1999 .

[15] Colombo S (2011), "Morocco at the Crossroads: Seizing the Window of Opportunity for Sustainable Development", [Online: web] Accessed 26 December 2011 URL: www.ceps.be/ceps/download/5490

[16] Zisenwine D (2011), "The Emergence of Nationalist Politics in Morocco: The Rise of the Independence Party and the Struggle Against Colonialism After World War II", African Studies Quarterly, 12 (4): 104.

[17] Zerhouni S (2004), "Morocco: Reconciling Continuity and Change", in Volker Perthes (eds.) Arab Elites: Negotiating the Politics of Change, Colorado: Lynne Rienner Publishers, Inc. 